Gunnell, D., Fouskakis, D., Rasmussen, F., et al (2003) Patterns of fetal and childhood growth and the development of schizophrenia and psychosis in young males: a cohort study. American Journal of Epidemiology, I58, 29I-300.

Renehan, A. G., Zwahlen, M., Minder, C., et al (2004) Insulin-like growth factor (IGF)-I, IGF binding protein-3, and cancer risk: systematic review and meta-regression analysis. Lancet, 363, 1346-1353.

Sandhu, M. S., Heald, A. H., Gibson, J. M., et al (2002) Circulating concentrations of insulin-like growth factor-I and development of glucose intolerance: a prospective observational study. Lancet, 359, 1740-1745.

Wahlbeck, K., Forsen, T., Osmond, C., et al (200I) Association of schizophrenia with low maternal body mass index, small size at birth, and thinness during childhood. Archives of General Psychiatry, 58, 48-52.

D. Gunnell Department of Social Medicine, Canynge Hall,Whiteladies Road, Bristol BS8 2PR, UK. E-mail: D.J.Gunnell@bristol.ac.uk

J. M. P. Holly Division of Surgery, University of Bristol, Bristol Royal Infirmary, Bristol, UK

\section{Pharmaceutical influence and psychiatrists: an introspection}

The Monday afternoon journal club brings us all together from the several community centres in the trust. Today, unexpectedly, the drug rep is not on time and the meeting has begun without lunch. Most of us are restless. It is difficult to listen when you are hungry. I catch myself looking out of the window, but I am also looking at the entrance to the room from the corner of my eye. Where is this drug rep anyway?

Gilbody et al (2004) have elaborated very topical concerns about the growing influence of direct-to-consumer advertising of psychotropic medications. In this movement, greater empowerment of consumer choice is used as a catch-phrase and, more importantly, the clinicians who oppose it stand accused of 'guarding professional territory' (Bonaccorso \& Sturchio, 2002). But to begin tracing this debate to its ethical roots, we ought to pause and first consider the merits of clinician-targeted advertising.

The editorial rightly states that $\$ 2.5$ billion was spent in the year 2000 on direct-to-consumer advertising in the USA. However, this was a small fraction of the massive $\$ 15.7$ billion spent on drug promotion as a whole (Rosenthal et al, 2002; Wolfe, 2002). Budgets for the same have increased exponentially over the past few years (Wolfe, 2002). With the introduction of the newer, more expensive atypical antipsychotics and selective serotonin reuptake inhibitors, this is particularly so in psychiatry. Since advertising in professional journals seems to be fairly static (as demonstrated by brief inspection of the number of drug advertisements in the Journal in any given month over the past decade), it can only be assumed that the bulk of this finance caters toward sponsoring conferences, hotel stays, lunches and other 'promotional' activities aimed at the clinician writing the prescriptions.

Such practice seems to be woven into the very fabric of the medical profession in general, and psychiatry in particular. Yet what evidence is there to suggest that this culture of happy symbiosis is beneficial to our patients?

Several studies have been done recently that investigate the possible changes in prescription patterns as a result of aggressive consumer-directed advertising. Surprisingly, on the other hand, there is very scant research indeed to elucidate the association of our prescription patterns and the influence of any concurrent clinician-directed advertising. Of the little evidence available, most suggests a worse scenario (Wang et al, 1999). Is there a professional bias that explains this paucity of interest?

Before riding our moral high horse and being outraged at the blurring of boundaries as the pharmaceutical industry makes independent forays into the public domain, should we not consider what boundaries we set big business when it entered our own fold? I imagine it would be difficult for a clinician who writes with a drug company pen, on a drug company pad, which he takes out of his drug company bag, to tell his patient not to invest much faith in drug company advertisements. On how many occasions do clinicians turn down offers by pharmaceutical companies to fund their attendance at conferences, flights abroad, hotel stays, social banquets, gifts? The list is long, and there is no such thing as a free lunch.

Meanwhile, in my own little way, I wait for the drug rep. The doctor presenting the paper rambles on. 'An intention to treat analysis would have been more appropriate to validate this particular therapy,' I think to myself. But at the same time I wonder, 'I hope it's the pretty lady from the risperidone company. She brings those lovely sandwiches from Marks \& Spencer'.

\section{Declaration of interest}

I regularly attend the twice-weekly journal clubs and case conferences at my centre, during which lunch is sponsored by pharmaceutical companies.

Bonaccorso, S. N. \& Sturchio, J. L. (2002) For and against: direct to consumer advertising is medicalising normal human experience: against. BMJ, 324, 910-91।.

Gilbody, S., Wilson, P. \& Watt, I. (2004) Direct-toconsumer advertising of psychotropics. An emerging and evolving form of pharmaceutical company influence. British Journal of Psychiatry, 185, I-2.

Rosenthal, M. B., Berndt, E. R., Donohue, J. M., et a (2002) Promotion of prescription drugs to consumers. New England Journal of Medicine, 346, 498-505.

Wang, T., Ausiello J. C. \& Stafford, R. S. (1999) Trends in antihypertensive drug advertising, 1985-1996. Circulation, 99, 2055-2057.

Wolfe, S. M. (2002) Direct to consumer advertising education or promotion? New England Journal of Medicine, 346, 524-526.

M. Husain Leeds Mental Health NHS Trust; correspondence to 39I Easterly Road, Oakwood Leeds LS8 2TR, UK.

E-mail: muzhusain@hotmail.com

\section{Defining delusion}

The clear definition of primary delusions helpfully provided by Owen et al (2004) includes both that one comes to believe new things (change in meaning) and arrives at such beliefs in a new way (transformation of experience). This requirement for a transformation of experience seems to me to require an abnormal mental mechanism that is permitted in a rationalist account of delusions. The distinction between primary and secondary delusions is one that eludes many authors (e.g. Hales et al, 1999: pp.432-434) in addition to myself and Professors van Os and Delespaul. We would differ I suppose in that while they view all delusions as secondary, I think those that do not share the mechanism of primary delusions are not really delusions at all.

Wernicke's work on aphasia suggested that mental functions were localised, but this is quite a separate issue from whether their mechanism is modular. This is evident in Wernicke's description of mental pathology as a 'loosening up of the firm network of association' (Jaspers, 1963: p. 536). Such an empiricist account of mental pathology is surely incompatible with modularity as proposed by the rationalist philosopher Fodor.

Hales, R., Yudofsky, S. C., Talbott, J. (eds) (1999) Textbook of Psychiatry. Washington, DC: Psychiatric Press.

Jaspers, K. (1963) General Psychopathology (7th edn) (trans. J. Hoenig \& M.W. Hamilton). Manchester: Manchester University Press. 